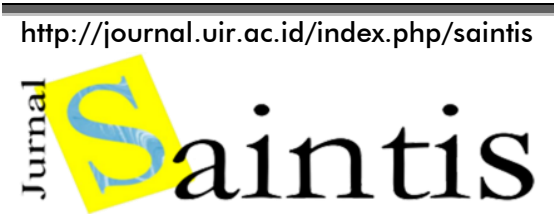

Volume 19 Nomor 01, April $2019: 9-14$

\title{
Studi Pengaruh Komposisi Pengisi Serat Alam Kayu Galam (Melalueca Leucadendra) Bentuk Serutan Pada Sifat Mekanik Dan Mikrostruktur Komposit Poliester Sebagai Material Untuk Aplikasi Bilah Kincir Angin
}

\author{
Study of Composite Composition Effect of Natural Shavings of Galam Wood Fiber (Melalueca \\ Leucadendra) on the Mechanical and Microstructure Properties of Polyester Composites as \\ Materials for the Windmill Blades Application
}

\author{
Andromeda Dwi Laksono 1,*, Ika Ismail1, Cahyaningtyas Ratna Ningrum ${ }^{1}$ \\ ${ }^{1}$ Program Studi Teknik Material dan Metalurgi, Jurusan Ilmu Kebumian dan Lingkungan,
} Institut Teknologi Kalimantan, Balikpapan

\begin{abstract}
* Corresponding author : andromeda@itk.ac.id
Tel.: +62-85-737-363-525; fax.:+62-54-285-308-00

Received: Feb 12, 2019; Accepted: Apr 23, 2019.

DOI: 10.25299/saintis.2019.vol19(1).2629
\end{abstract}

\section{Abstrak}

Sebagai alternatif sumber energi konvensional, energi angin merupakan salah satu energi alternatif yang banyak dikembangkan. Pemanfaatan energi ini tidak lepas dari alat pengonversinya, kincir angin. Salah satu komponen kincir angin yang cukup penting adalah bilah. Bilah sering mengalami masalah berupa pengikisan pada bagian permukaannya akibat benturan dengan oleh partikel yang terbawa oleh angin yang dapat mengakibatkan fungsi bilah tidak optimal. Sehingga, dibutuhkan material pengganti yang lebih kuat tetapi ringan, yakni komposit. Komposit yang digunakan adalah komposit serat alam (serat Melaleuca leucadendra-poliester). Dalam penelitian ini akan dianalisa pengaruh fraksi volume serat berbentuk serutan terhadap kekuatan tarik, kelenturan dan ketangguhan. Pembuatan komposit serat alam Kayu Galam (Melaleuca leucadendra)-poliester dengan cara mencampurkan resin, katalis dan serat Kayu Galam yang berbentuk serutan kemudian dicetak didalam cetakan yang telah dilapisi alumunium foil. Sampel kemudian dilakukan pengujian kekuatan tarik dengan standar ASTM D 638, pengujian tekuk dengan standar ASTM D 790 serta pengujian impak dengan standar ASTM D 6110. Metode yang digunakan dalam pembuatan adalah metode hand lay-up. Hasil dari penelitian ini adalah nilai optimum yang dicapai yaitu 70\% serat pada semua uji mekanik. Didapatkan nilai kekuatan tarik berada sebesar 13,07 MPa, kekuatan tekuk optimum 36,8 MPa dan nilai optimum dari kekuatan impak sebesar 590,39 MPa.

Kata Kunci: Energi Angin, Kincir Angin, Komposit, Melaleuca leucadendra, Poliester

\section{Abstract}

As an alternative to conventional energy sources, wind energy is one of the many alternative energies that have been developed. The utilization of this energy is inseparable from its conversion tool, windmills. One component of the windmill that is quite important is the blade. Blades often experience problems in the form of erosion on the surface due to collisions by particles carried by the wind which can cause the blade function to be not optimal. So, it takes a replacement material that is stronger but lighter, namely composite. The composites used were natural fiber composites (Melaleuca leucadendra-polyester fibers). In this study, the effect of the volume fraction of fiber in the form of shavings on tensile strength, flexibility, and toughness will be investigated. The making of natural fiber composites of Galam Wood (Melaleuca leucadendra) -polyester by mixing resin, catalyst, and Galam Wood fiber in the form of shavings is then printed in a mold that has been coated with aluminum foil. Samples were then tested for tensile strength with ASTM D 638 standard, bending test with ASTM D 790 standard and impact testing under ASTM D 6110 standard. The method used in manufacturing was the hand lay-up method. The result of this study is the optimum value achieved is $70 \%$ fiber in all mechanical tests. Obtained tensile strength values of 13.07 MPa, the optimum bending strength of $36.8 \mathrm{MPa}$ and the optimum value of impact strength of $590.39 \mathrm{MPa}$.

Keywords: Wind Energy, Windmill, Composite, Melaleuca leucadendra, Polyester

\section{PENDAHULUAN}

Kebutuhan energi di Indonesia umumnya semakin meningkat seiring meningkatnya pertambahan penduduk. Pemanfaatan energi konvensional yang berasal dari fosil masih mendominasi sebagai sumber energi yang digunakan. Energi konvensional tersebut berasal dari sumber energi yang tidak terbarukan, sehingga potensi cadangannya semakin berkurang . Hal tersebut mendasari manusia mencari sumber energi alternatif untuk memenuhi kebutuhan energi. Beberapa energi alternatif yang dapat dikembangkan mencakup energi angin, surya, mikro hidro serta biodiesel [1].

Energi angin di Indonesia memiliki potensi yang cukup besar untuk dimanfaatkan. Berdasarkan data yang diperoleh, potensi energi angin di 
Indonesia mencapai 9,286 MW bila dikonversikan menjadi energi listrik, dimana saat tahun 2004 penggunaan nya masih kurang dari 0,5 MW [2]. Pemanfaatan energi angin tersebut tergolong masih rendah. Untuk memanfaatkan energi angin tersebut dibutuhkan alat pengonversi energi yang dapat mengonversi energi kinetik angin menjadi energi listrik. Alat pengonversi tersebut berupa kincir angin. Pembangkit listrik dari turbin angin memiliki kelebihan dalam perolehan hasil energi yang bersih, bebas dari hasil polusi dan persebarannya bisa dilakukan di wilayah garis lepas pantai yang berpotensi memiliki energi angin yang besar [3].

Kincir angin merupakan alat konversi dari energi angin menjadi energi listrik. Pada awalnya, energi angin ditangkap oleh bilah. Selanjutnya energi angin yang dihasilkan dan putaran bilah tersebut membuat generator berputar menghasilkan tegangan AC 3 fasa. Tegangan tersebut dialirkan menuju controller. Pada controller, tegangan AC tersebut dikonversikan menjadi tegangan DC. Hal tersebut disebabkan baterai yang merupakan media penyimpanannya menyimpan dalam bentuk DC. Selanjutnya, tegangan tersebut dialirkan kembali menuju data logger untuk dilakukan perekaman data atau penyimpanan data. Data yang disimpan dalam data logger ini merupakan data tegangan dan arus kemudian dilanjutkan dengan penyimpanan pada baterai. Untuk menggunakan listrik dari baterai ini dikonversi ke bentuk AC melalui inverter [4].

Salah satu komponen yang penting dalam kincir angin adalah blade atau bilah. Fungsi dari bilah adalah menangkap angin yang kemudian diteruskan ke generator [5]. Sebagai komponen yang berhadapan dengan angin, bilah dari kayu sering mengalami permasalahan dengan bagian permukaannya. Salah satunya akibat benturan partikel dan debu yang terbawa oleh angin [6]. Komposit serat alam dipilih karena memiliki kelebihan diantaranya densitas yang rendah, tidak abrasif, biodegradability, ketersediaan bahan baku yang melimpah dan harganya yang murah [7]. Serat yang digunakan dalam penelitian ini merupakan serat Kayu Galam.

Kayu Galam (Melaleuca leucadendra) merupakan kayu endemik yang umum tumbuh di wilayah rawa. Kayu yang memiliki kekuatan dan keawetan yang baik ini digunakan sebagai penyangga kontruksi, kayu bakar, kayu arang dan lantai jembatan (sifat papan partikel). Potensi Kayu Galam di Kalimantan sangat melimpah sehingga harganya terjangkau. Hal ini menjadi nilai tambah bagi Kayu Galam untuk menjadi aplikasi yang bernilai lebih tinggi. Material penyusun komposit dalam penelitian ini menggunakan poliester dan Kayu Galam. Jenis kayu ini dipilih karena ketersediaannya di alam yang berlimpah serta merupakan jenis kayu yang memiliki kekuatan dan keawetan yang baik. Fokus pada penelitian ini adalah untuk mengetahui sifat mekanik pada material komposit serat alam dengan memvariasikan fraksi volume serat berbentuk serutan dengan mengukur kekuatan tarik, kekuatan tekuk dan kekuatan impak dari komposit serat alam.

\section{METODOLOGI}

\section{Peralatan dan Bahan Penelitian}

Bahan

1. Resin Poliester

Merupakan bahan matriks yang digunakan dalam pembuatan komposit. Resin yang digunakan adalah jenis poliester tak jenuh.

2. Serutan Kayu Galam

Merupakan serat Kayu Galam yang berbentuk serutan. Serat Kayu Galam berbentuk serutan ini diperoleh dengan cara mengetam Kayu Galam menggunakan alat ketam. Ukuran serutan ini 2 mesh.

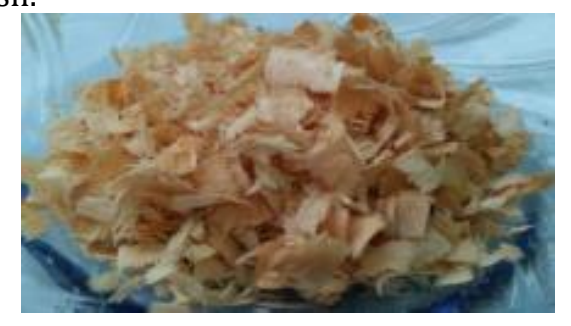

Gambar 1. Serutan Kayu Galam

3. Katalis

Merupakan zat yang ditambahkan untuk mempercepat reaksi yang terjadi antara resin dan serat.

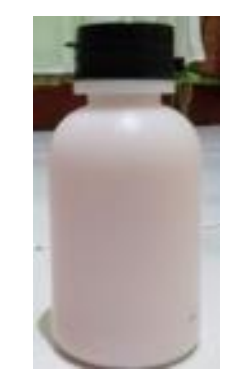

Gambar 2. Katalis

Peralatan

Alat- alat yang digunakan dalam penelitian ini terdiri dari dua kelompok peralatan yang digunakan yakni untuk pembuatan sampel dan pengujian sampel. Peralatan pembuatan sampel terdiri dari:

1. Pengaduk

Pengaduk digunakan untuk mengaduk bahan.

2. Cetakan Spesimen

Cetakan digunakan untuk mencetak spesimen uji. Cetakan dilapisi oleh alumunium foil pada bagian bawah dan dinding-dindingnya untuk menghindari cairan matriks keluar dari cetakan spesimen.

3. Timbangan

Timbangan digunakan untuk menimbang serat Kayu Galam dan poliester yang akan digunakan.

4. Wadah Pengaduk

Wadah digunakan untuk mencampurkan serat, resin dan katalis. 


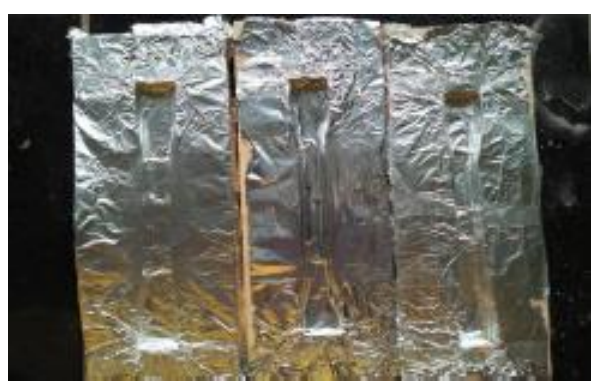

Gambar 3. Cetakan Spesimen

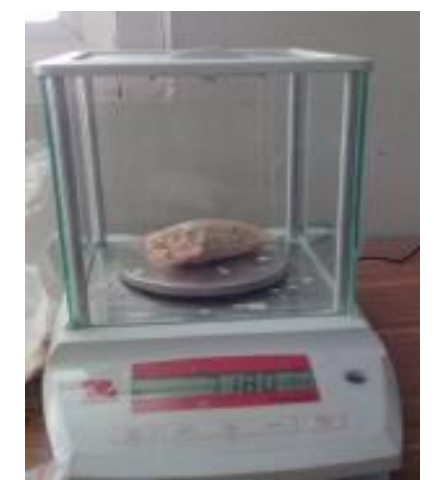

Gambar 4. Cetakan Spesimen

\section{Pengujian}

1. Mesin Uji Tarik

Mesin uji tarik digunakan untuk menguji kekuatan tarik dari komposit.

2. Mesin Uji Tekuk

Mesin uji tekuk digunakan untuk menguji kelenturan dari komposit.

3. Mesin Uji Impak

Mesin uji impak digunakan untuk menguji ketangguhan komposit.

4. Mikroskop Optik

Mikroskop optik digunakan untuk mengetahui morfologi, distribusi dan dispersi serat pada komposit.

\section{Prosedur Penelitian}

\section{Persiapan Serat Alam Kayu Galam}

Berikut adalah tahapan persiapan serat alam Kayu Galam diantaranya:

1. Kayu Galam dibersihkan dari kulit ari dan kotoran yang menempel.

2. Kayu diketam menjadi bentuk serutan.

3. Hasil kayu yang sudah diketam menjadi serutan, kemudian dijemur untuk mengurangi kadar air.

4. Setelah penjemuran selesai, serat tersebut diayak menggunakan ayakan ukuran 2 mesh.

5. Setelah ukuran serutan sesuai ketentuan, dilakukan penimbangan terhadap bahan serat tersebut.

6. Penimbangan dilakukan menggunakan timbangan digital sesuai dengan fraksi volume yang ditentukan.

\section{Pembuatan Komposit}

Penelitian ini menggunakan komposit berbahan dasar serat Kayu Galam yang diperoleh secara komersial dari toko bangunan sedangkan resin poliester merk Yukalac 157-BQTN diperoleh secara komersial dari UD. Mahakam Fiber Glass Samarinda. Dalam penelitian ini akan membuat tiga jenis spesimen, yakni spesimen untuk pengujian tarik, spesimen untuk pengujian tekuk dan spesimen untuk pengujian impak. Pembuatan komposit dilakukan dengan metode hand lay up.

Berikut tahapan pembuatan komposit dengan metode hand lay-up:

1. Menyiapkan wadah pencampuran, pengaduk, resin, katalis dan serat yang akan dibuat menjadi komposit.

2. Mencampurkan serat dan resin ke dalam wadah kemudian diaduk hingga tercampur rata.

3. Setelah campuran tercampur rata, diberikan katalis sebanyak 8-10 tetes ke dalam campuran tersebut dan lanjutkan pencampuran kembali hingga rata.

4. Hasil pencampuran tersebut dituangkan ke dalam cetakan yang sudah disediakan.

5. Tahap terakhir, mengeringkan komposit di temperatur ruang.

Proses Pembuatan Cetakan

Berikut tahapan pembuatan cetakan komposit :

1. Menggambar desain cetakan di kertas. Desain disesuaikan dengan ASTM D 638 untuk cetakan uji tarik, ASTM D790 untuk cetakan uji tekuk dan ASTM D 6110 untuk cetakan uji impak.

2. Desain yang sudah jadi digunting kemudian ditempelkan pada triplek.

3. Setelah itu, triplek dipotong dengan gergaji triplek mengikuti bentuk desain yang ditempelkan.

4. Selanjutnya, merapikan sisi potongan gergaji menggunakan amplas.

5. Cetakan yang sudah jadi dilapisi alumunium foil agar mudah pelepasan saat komposit sudah kering.

\section{HASIL DAN PEMBAHASAN}

\section{Hasil Proses Pembuatan Komposit}

Proses pembuatan komposit dilakukan dengan metode hand lay up. Komposit dicetak sesuai dengan spesimen uji tarik sesuai standar ASTM D 638, spesimen uji impak sesuai standar D 6110 dan spesimen uji tekuk sesuai standar ASTM D790. Komposit yang dibuat dengan orientasi serat acak dengan bentuk serat berupa serutan.

Berdasarkan Gambar 5, secara makro persebaran serat dari komposit tersebut sudah merata. Pada Gambar 6, dapat terlihat bahwa spesimen komposit tersebut getas. Hal tersebut 
ditinjau dari pola patahannya dan tidak adanya pertambahan panjang yang signifikan di sekitar area yang patah.

Berdasarkan Gambar 7, fraksi volume berpengaruh terhadap warna dari spesimen dimana fraksi yang rendah memiliki warna lebih terang (Gambar 7b) dibandingkan fraksi volume yang tinggi (Gambar 7a). Hal tersebut disebabkan karena pengisi dari kompositnya semakin banyak sehingga lebih gelap.

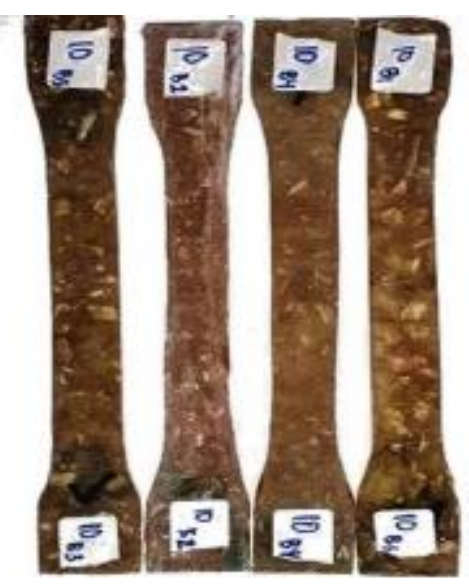

Gambar 5. Spesimen Uji Tarik

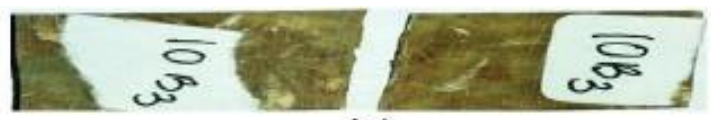

Gambar 6. Pola Patahan Spesimen Uji Tarik pada Fraksi Volume Serat 10\%

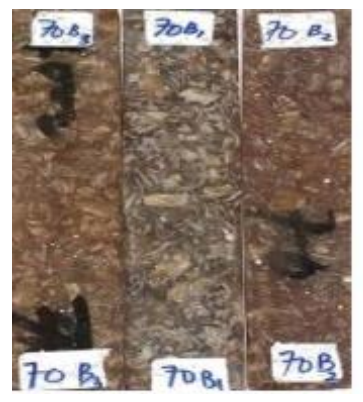

(a)

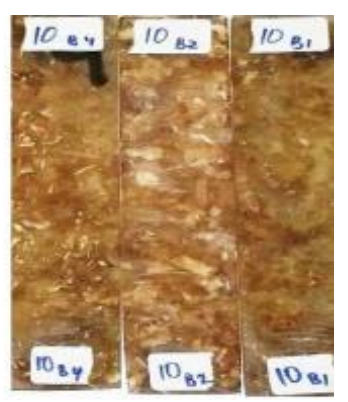

(b)
Gambar 7. Pola Patahan Spesimen Uji Tarik pada Fraksi Volume Serat (a) 30\% (b) 10\%

\section{Hasil Pengujian Sifat Mekanik Komposit}

\section{Kekuatan Tarik Komposit}

Pada Gambar 8, terlihat perbandingan nilai kekuatan tarik dari poliester murni, Kayu Galam murni, dan poliester-serat (fraksi volume $10 \mathrm{wt} \%$, $30 \mathrm{wt} \%, 50 \mathrm{wt} \%, 70 \mathrm{wt} \%)$. Pada fraksi volume 10 wt\%, nilai kekuatan tarik komposit berpenguat serat sebesar 5,89 MPa. Kemudian pada fraksi volume $30 \mathrm{wt} \%$, nilai kekuatan tarik komposit berpenguat serat sebesar 6,01 MPa. Lalu pada fraksi volume 50 wt\%, nilai kekuatan tarik komposit berpenguat serat sebesar 7,74 MPa dan pada fraksi volume $70 \mathrm{wt} \%$, nilai kekuatan tarik berpenguat serat sebesar 13,07 MPa.

Semakin tinggi pengaruh fraksi volume serat pada komposit, maka kekuatan tariknya semakin tinggi bahkan pada fraksi volume 70 wt\% lebih besar dibandingkan material asalnya yaitu poliester murni, sebesar 7,05 MPa dan Kayu Galam murni, sebesar 5,43 MPa.

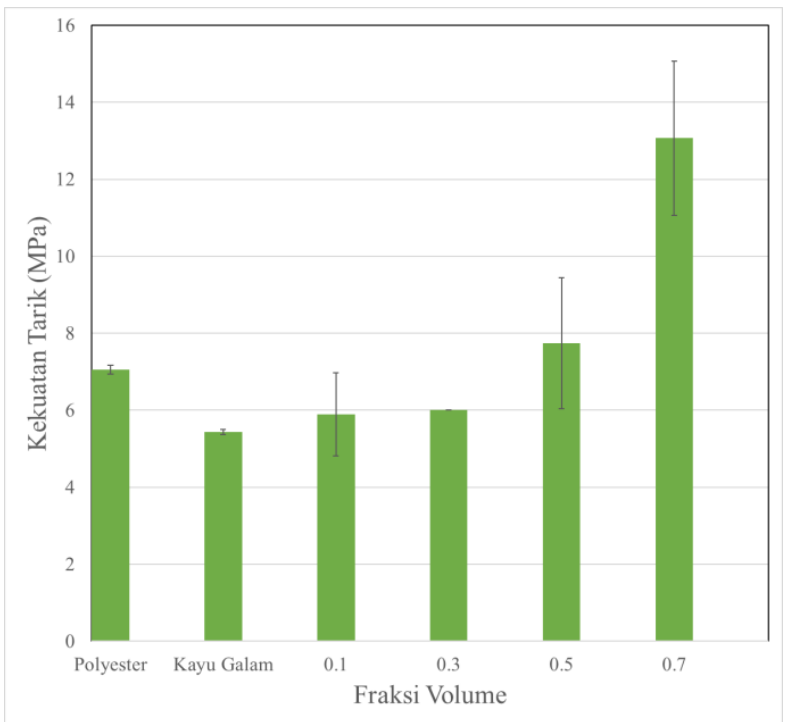

Gambar 8. Grafik Kekuatan Tarik Poliester, Kayu Galam, Poliester-Serat (fraksi volume $10 \mathrm{wt} \%, 30$ wt $\%, 50 w \mathrm{t} \%, 70 \mathrm{wt} \%$ )

Namun, peningkatan optimum kekuatan tarik komposit serat alam dari kayu bangkirai belum memenuhi kriteria kekuatan tarik yang berlaku sebesar 57,9 MPa [8]. Diperlukan variasi arah serat, ukuran serat, dan jenis komposit (seperti laminat) pada penelitian selanjutnya untuk mengetahui efek kekuatan tarik.

Kekuatan Tekuk Komposit

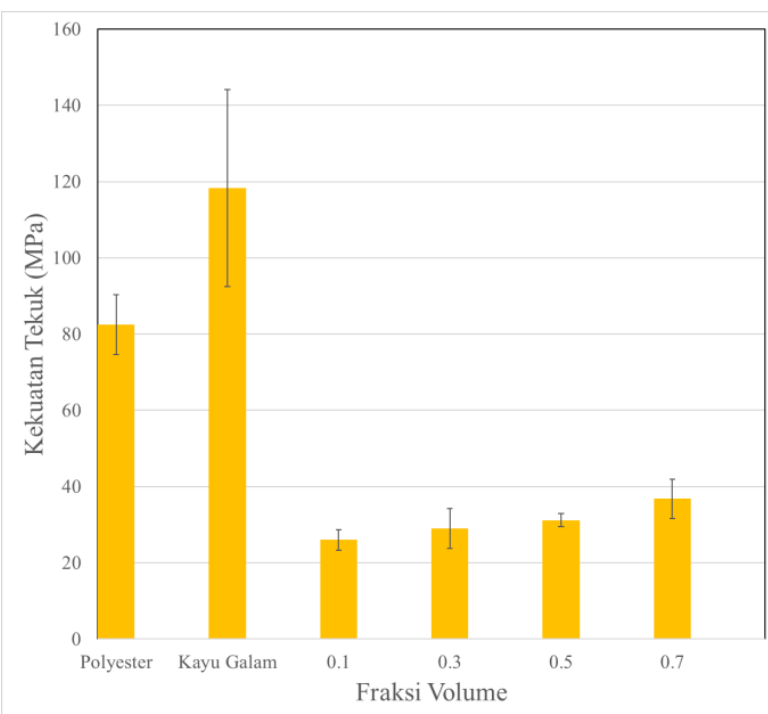

Gambar 9 Grafik Kekuatan Tekuk Poliester, Kayu Galam, Poliester-Serat (fraksi volume $10 \mathrm{wt} \%, 30$ wt $\%, 50 w t \%, 70 w t \%$ )

Pada Gambar 9, terlihat perbandingan nilai kekuatan tekuk dari poliester murni, Kayu Galam 
murni, poliester-serat (10 wt $\%, 30 \mathrm{wt} \%$, $50 \mathrm{wt} \%$, 70 wt\%). Pada fraksi volume $10 \%$, nilai kekuatan tekuk komposit berpenguat serat sebesar $26 \mathrm{MPa}$. Kemudian pada fraksi volume 30\%, nilai kekuatan tekuk berpenguat serat sebesar $29 \mathrm{MPa}$. Lalu pada fraksi volume $50 \%$, nilai kekuatan tekuk komposit berpenguat serat sebesar 31,2 MPa dan pada fraksi volume $70 \%$, nilai kekuatan tekuk berpenguat serat sebesar 36,8 MPa .

Berdasarkan hasil penelitian pada Gambar 9 menunjukan bahwa nilai kelenturan dari komposit berpenguat serat lebih rendah dibandingkan bahan pembentuknya (Kayu Galam sebesar 118,32 MPa dan poliester $82,48 \mathrm{MPa}$ ). Peningkatan nilai yang kecil pada hasil pengujian juga dapat menunjukan bahwa peningkatan fraksi volume berpengaruh kecil terhadap peningkatan nilai kekuatan tekuk. Menurut Pandey dkk., 2016, faktor pembuatan spesimen komposit dan distribusi serat dapat menyebabkan penurunan nilai kelenturan dari komposit hand lay-up manual [9]. Hal ini disebabkan karena ketika proses pembuatan material komposit dengan metode hand lay up manual, akan ada kecenderungan serat berkumpul pada titik tertentu dan distribusi serat yang tidak merata. Di sisi lain, dinyatakan bahwa kekuatan tekuk dari komposit memenuhi standar dari kelenturan yang ada pada kayu pinus untuk bilah kincir angin sebesar 8,10 MPa [8].

Kekuatan Impak Komposit

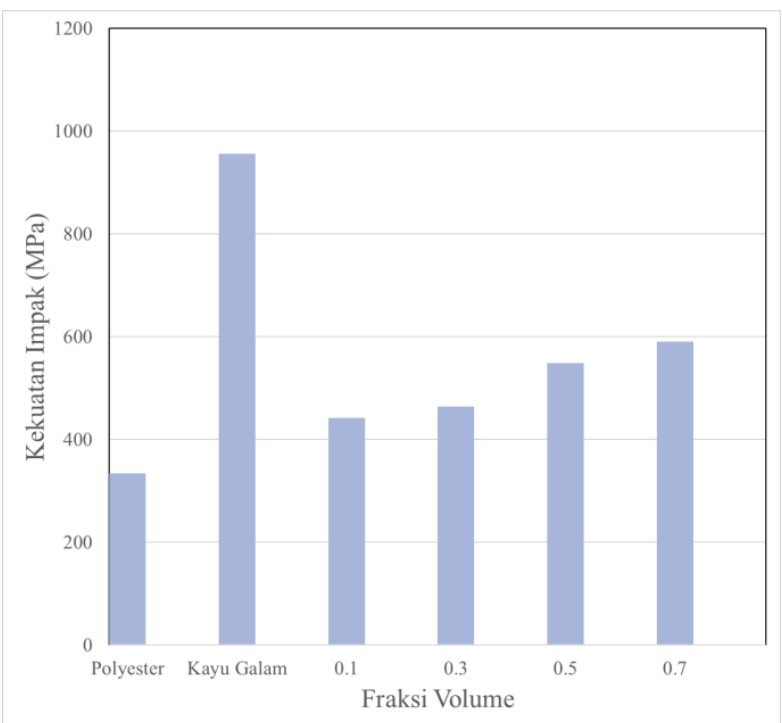

Gambar 10 Grafik Kekuatan Impak Poliester, Kayu Galam, Poliester-Serat (fraksi volume $10 \mathrm{wt} \%, 30$ wt $\%, 50$ wt $\%, 70 w t \%)$

Pada Gambar 10, terlihat perbandingan nilai kekuatan impak dari poliester murni, Kayu Galam murni, polyester-serat (10 wt\%, 30 wt\%, 50 wt\%, 70 wt\%). Pada fraksi volume 10\%, nilai kekuatan impak komposit berpenguat serat sebesar 442,23 MPa, kemudian pada fraksi volume 30\%, nilai kekuatan impak berpenguat serat sebesar
463,61 MPa. Lalu pada fraksi volume 50\%, nilai kekuatan impak komposit berpenguat serat sebesar $548,42 \mathrm{MPa}$ dan pada fraksi volume $70 \%$, nilai kekuatan impak berpenguat serat sebesar 590,39 MPa.

Dari hasil pada Gambar 10 menunjukkan bahwa penambahan jumlah fraksi volume serat menyebabkan peningkatan ketahanan komposit terhadap beban kejut [10]. Semakin tinggi nilai kekuatan impaknya, semakin tinggi nilai ketangguhannya. Dalam penelitian ini diperoleh nilai kekuatan impak komposit lebih rendah dibandingkan dengan kekuatan impak Kayu Galam namun lebih tinggi dibandingkan nilai kekuatan impak poliester.

Pada pengujian impak ini, sudut awal $(\alpha)$ yang digunakan sebesar $30^{\circ}$ dengan sudut akhir $(\beta)$ yang bervariasi. Sudut awal merupakan sudut yang dibentuk lengan bandul dengan spesimen sebelum diayunkan mematahkan spesimen. Sedangkan sudut akhir merupakan sudut yang terjadi ketika lengan bandul sudah diayunkan dan terhambat oleh adanya spesimen. Sudut akhir $(\beta)$ pada poliester murni sebesar $28,5^{\circ}, \beta$ pada kayu galam sebesar $25,5^{\circ}, \beta$ pada komposit ber-penguat serat $10 \%$ sebesar $28^{\circ}$, $\beta$ pada komposit ber-penguat serat $30 \%$ sebesar $27,9^{\circ}, \beta$ pada komposit ber-penguat serat $50 \%$ sebesar $27,5^{\circ}$, dan $\beta$ pada komposit ber-penguat serat $70 \%$ sebesar $27,3^{\circ}$. Perbedaan nilai antara sudut awal dan akhir menunjukkan terdapat energi yang diserap oleh spesimen ketika dilakukan pengujian. Nilai sudut akhir $(\beta)$ yang kecil menunjukan bahwa energi yang diserap oleh spesimen lebih besar dan menghasilkan nilai kekuatan impak yang besar.

Berdasarkan penelitian dari Kretschmann mengenai nilai kekuatan impak kayu pinus yang diaplikasikan pada bilah kincir angin menunjukan bahwa hasil pengujian dari komposit Kayu Galam memenuhi kriteria kekuatan tarik yang berlaku sebesar 163 $\mathrm{MPa}$ [8].

\section{Pengamatan Mikrostruktur}

Pengamatan mikrostruktur dalam penelitian ini menggunakan mikroskop optik yang berada di Program Studi Teknik Material dan Metalurgi, Institut Teknologi Kalimantan. Pengamatan ini bertujuan untuk menganalisa persebaran serat secara mikro dan melihat adanya fiber pull out dalam komposit. Dari beberapa gambar di bawah, terdapat spesimen penelitian yang menunjukan fiber pull out.
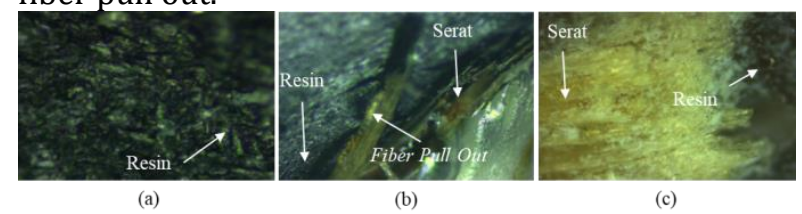

Gambar 11 Pengamatan mikrostruktur pada (a) Poliester Murni, (b) Komposit Fraksi Volume Serat 10\%, dan (c) Komposit Fraksi Volume Serat 70\% 
Gambar 11a merupakan penampakan dari patahan spesimen poliester murni. Dari penampakan tersebut terlihat warna gelap yang merupakan resin sedangkan yang berwarna putih sedikit tersebut merupakan pantulan dari cahaya yang mengenai resin. Patahan tersebut termasuk jenis patah getas karena tidak menunjukkan adanya serabut pada pola patahannya. Perbesaran yang digunakan dalam pengambilan gambar ini adalah perbesaran 10x. Sedangkan pada Gambar 11b merupakan penampakan dari patahan pada komposit berpenguat serat $10 \%$. Pada gambar tersebut terlihat fiber pull out pada bagian tepi gambar. Fiber pull out dapat mengindikasikan ikatan antara serat dengan matriks kurang kuat, hal ini tentunya mengurangi sifat mekanik dari komposit tersebut dikarenakan ikatan antara matriks dan seratnya lemah [11]. Gambar 11c merupakan penampakan patahan spesimen. Dalam gambar tersebut terlihat komposisi serat lebih banyak dibandingkan komposisi resin. Semakin banyak jumlah serat yang terdapat dalam komposit, secara teori akan lebih kuat karena serat tersebut berfungsi sebagai penguat [11].

\section{KESIMPULAN}

Pada penelitian kali ini dapat disimpulkan bahwa fraksi volume serat berpengaruh terhadap sifat kelenturan, ketangguhan dan kekuatan tarik dari komposit serat alam Kayu Galam dengan poliester jenuh dimana komposit yang memiliki fraksi volume serat semakin tinggi memiliki nilai yang lebih tinggi. Hasil dari penelitian ini adalah nilai optimum yang dicapai yaitu $70 \%$ serat pada semua uji mekanik. Didapatkan nilai kekuatan tarik berada sebesar 13,07 MPa, kekuatan tekuk optimum 36,8 MPa dan nilai optimum dari kekuatan impak sebesar 590,39 MPa. Hasil kelenturan dan kekuatan impak pada Kayu Galam - poliester sudah memenuhi syarat untuk aplikasi bilah kincir angin. Namun, tidak pada kekuatan tarik. Untuk analisa morfologi, pola patahan pada serat menunjukan muncul fiber pull out pada serat. Hal tersebut mempengaruhi penurunan kekuatan tarik dari komposit, dimana fiber pull out ini mengindikasikan ikatan antara serat dan matrik kurang baik. Pada serat $70 \%$ memiliki nilai kekuatan paling tinggi ditunjukkan dengan komposisi serat lebih banyak dan tidak tampak fiber pull out. Penelitian selanjutnya diperlukan variasi arah serat, ukuran serat, dan jenis komposit (seperti laminat) untuk mengetahui efek uji mekanik.

\section{ACKNOWLEDGMENT}

Penulis mengucapkan terima kasih banyak untuk almarhum Bapak Ika Ismail atas kesempatan menulis artikel ilmiah ini.

\section{REFERENSI}

[1] Syahrul, "Prospek Pemanfaatan Energi Angin Sebagai Energi Alternatif Di Daerah Pedesaan," Media Elektrik, vol. 3, no. 2, 2008.

[2] A. Rachman, "Analisis dan Pemetaan Potensi Energi Angin di Indonesia," Fakultas Teknik Program Studi Teknik Mesin, Universitas Indonesia, Depok, 2008.

[3] D. Kurniawan, "Unjuk Kerja Turbin Angin Propeller 4 Sudu Berbahan Komposit Berdiameter $100 \mathrm{~cm}$ dengan Lebar Maksimum Su," Yogyakarta, Daerah Istimewa Yogyakarta, Indonesia, 2016.

[4] L. A. Nusantara, "Pengenalan Teknologi Pemanfaatan Energi Angin," Tasikmalaya, 2014.

[5] H. Piggott and N. C. f. A. Technology, Windpower Workshop: Building Your Own Wind Turbine. Centre for Alternative Technology, 1997.

[6] E. Sagol, M. Reggio, and A. Ilinca, "Issues concerning roughness on wind turbine blades," Renewable and Sustainable Energy Reviews, vol. 23, pp. 514-525, 2013/07/01/ 2013.

[7] G. R. Kalagi, R. Patil, and N. Nayak, "Experimental Study on Mechanical Properties of Natural Fiber Reinforced Polymer Composite Materials for Wind Turbine Blades," Materials Today: Proceedings, vol. 5, no. 1, Part 3, pp. 2588-2596, 2018/01/01/ 2018.

[8] D. Kretschmann, "General Technical Report," New York2000.

[9] P. Pandey, D. Bajwa, C. Ulven, and S. Bajwa, "Influence of Hybridizing Flax and HempAgave Fibers with Glass Fiber as Reinforcement in a Polyurethane Composite," (in eng), Materials (Basel, Switzerland), vol. 9, no. 5 , p. $390,2016$.

[10] M. B.N. Rahman and T. Suwanda, "Pengaruh Fraksi Volume Serat terhadap Peningkatan Kekuatan Impak Komposit Berpenguat Serat Nanas-Nanasan (Bromeliaceae) Kontinyu Searah dengan Matrik Unsaturated Polyester," SEMESTA TEKNIKA, vol. 13, no. 2, pp. 137-144, 2010.

[11] D. D, "Pengaruh Persentase Massa Serat Terhadap Sifat Mekanis Komposit Matriks Polipropilen Dengan Penguat Serat Ampas Tebu Pada Proses Injection Molding," 2014.

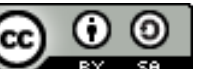

This is an open access article which means that all content is freely available without charge to the user or his/her institution. Jurnal Saintis allows the author(s) to hold the copyright without restriction. The copyright in the text of individual articles (including research articles, opinion articles, and abstracts) is the property of their respective authors distributed under the terms of the Creative Commons Attribution-ShareAlike 4.0 International License (https://creativecommons.org/licenses/by-sa/4.0/) which permits unrestricted use, distribution, and reproduction in any medium. Users are allowed to read, download, copy, distribute, search, or link to full-text articles in this journal without asking by giving appropriate credit, provide a link to the license, and indicate if changes were made. 